control of the sources of power in modern government "The key to this problem . . . is the extent to which we can gain control of the enormous new sources of power which the scientists and engineers have put at our disposal." Mr Benn goes on to argue that the use and abuse of power that derives from the application of scientific knowledge is exactly analogous to the power exercised by the mediaeval barons, that modern industry and the pace of growth and innovation have evoked the need for closer control of industrial enterprises and that there is now an urgent need to strengthen political control of the military and to establish, for the first time, political control over what $\mathrm{Mr}$ Benn considers to be the uncontrolled sources of power represented by education and the professions.

Mr Benn's attack on the education system, and especially the universities, is characteristically overdrawn. He complains that "our educational system is dominated from the top by the universities" and that the universities "in the name of academic freedom have insulated themselves from democratic accountability" behind the shield of the University Grants Committee. He also alleges that a variety of professions-medicine, science, economics and sociology-have sought to insulate themselves against democratic control behind a barricade of academic qualifications and the pretension of expertise. The trouble with Mr Benn's description of the problem of democracy is that his statement of it corresponds only loosely with what the real world is like. In the first place, for example, the University Grants Committee is nothing like the autonomous barony that he describes. For one thing, the committee is often held by parliamentarians themselves to be an enlightened piece of public administration. Parliament has consistently taken the view that Britain needs an independent university system, able to decide for itself where resources should be allocated within a budget fixed by the government. If $\mathrm{Mr}$ Benn had complained that the committee's success in creating a more rational pattern within the universities has often fallen short of its own ambitions and of the national need, he would have won and not lost some of his friends. But does he really think that it would be possible, let alone desirable, to take university teachers on to the civil service payroll and to have decisions about priorities in university development complicated by the advocacy by members of parliament of the interests of their local universities? In Mr Benn's complaints against the vested interests of science and the other professions, it is much harder to tell precisely what targets he has in mind. No doubt the research councils would be prominent among his list of baronial vested interests but, as luck will have it, the past year has seen how easily the government, when it chooses, can change the methods by which the research councils are democratically controlled. If anybody is to blame for the slowness with which the need to do this is recognized, it is the government and not the profession of science that should be blamed. Institutions such as the Royal Society might legitimately be complained against on the grounds that they are not representative of or responsive to science as a whole, but here again they are held by government to be a useful means of administering the public interest in science when too formal a link with government as such is a disadvantage- the new International Institute of Applied Systems Analysis is a good example. In short, $\mathrm{Mr}$
Benn's plea that democracy should be made more real is entirely to be supported but his analysis of present defects leaves so much to be desired that those who know his case in detail must doubt the usefulness of his remedies.

\section{Policy for Australio}

THE Australian elections on December 2 are likely to be the first for several years in which questions of science policy will have played an important part. Over the years, it has become customary for Australian governments to avoid the question of how best to spend money on scientific research by leaving the job to the Commonwealth Scientific and Industrial Research Organization, the chief channel for public expenditure on research and development in Australia. And nobody will quarrel with the boast of successive governments of Australia that the CSIRO is one of the best organizations of its kind anywhere in the world. In the past few years, however, the organization has increasingly run into criticism. and in recent months it has been fiercely criticized by industrialists for being too detached from practical and commercial considerations. A part of the complaint is that the CSIRO is too often tempted towards unpractical projects, but it is also fair to say, as industrialists have been saying, that applied research carried out within government establishments is bound to be, in some degree, less effective than it would be if it were more fully integrated with production. The Liberal government has this year set up the Advisory Committee on Science and Technology, but the Labour party which now appears to be hopeful of winning power again, would apparently go further. Dr Moss Cass said in a radio interview on October 8 that his party would set up a Ministry for Science and Technology. Experience elsewhere has shown that ministries of science are often effective ways of isolating research and development from the rest of public administration. But even if the Labour Party does now return to power, there is no reason why it should not gracefully forget this election pledge as many other newly elected governments have done before.

\section{Year's Ago}

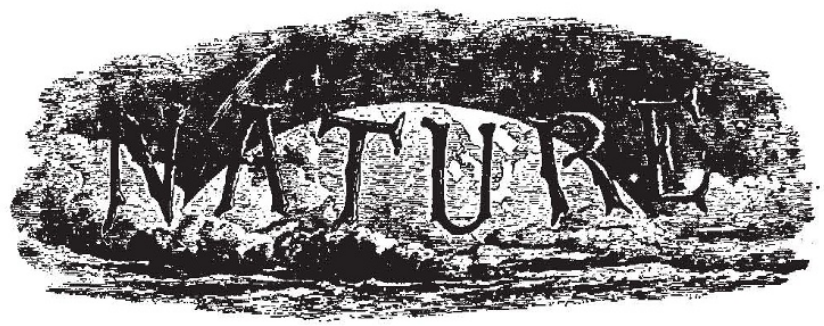

IN reference to the Swiney Lectureship, which we announced recently as having become vacant, we venture to hope the post will not be thrown away on some one who is already well off, and has taken his place in life, but that it will be given to some young man who has shown himself well qualified for scientific research, and who may thus be enabled to devote his time to investigations which may lead to results of enduring value. Several eminent men have already held this lectureship, including, we believe, Dr. Canpenter.

From Nature, 7, 34, November 14, 1872. 